\title{
Performance of coconut shell ash and palm kernel shell ash as partial replacement for cement in concrete
}

\author{
Oyedepo OJ *, Olanitori LM and Akande SP
}

\author{
Department of Civil and Environmental Engineering, Federal University of Technology Akure, Nigeria. \\ * Corresponding Author: oyedepoo@yahoo.co.uk
}

\begin{abstract}
High cost of cement used as binder in the production of concrete has led to a search for alternative. Using a mix design ratio of 1:2:4 and water binder ratio of 0.63 , concrete cubes were casted using varying ordinary Portland cement (OPC): palm kernel shell ash (PKSA) and ordinary Portland cement (OPC): coconut shell ash (CSA) ratios of 100:0, 90:10, 80:20, 70:30, 60:40 and 50:50 respectively. This research reveal that partial replacement of cement with 20\% PKSA and CSA in concrete gives an average optimum compressive strength of $15.4 \mathrm{~N} / \mathrm{mm}^{2}$ and $17.26 \mathrm{~N} / \mathrm{mm}^{2}$ respectively at 28 days. While, the optimum value of compressive strength obtained at 28 days is $20.58 \mathrm{~N} / \mathrm{mm}^{2}$ at $10 \%$ replacement with CSA. The value obtained is suitable for both light weight and heavy weight concrete respectively. Thus, the research show that the use of PKSA and CSA as a partial replacement for cement in concrete, at lower volume of replacement, will enhance the reduction of cement usage in concretes, thereby reducing the production cost and the environmental pollution caused by the dumping of the agricultural waste.
\end{abstract}

Key words: Cement, Concrete, Compressive Strength, Cost, Pollution.

\section{Introduction}

Concrete is the widely used number one structural material in the world today, high cost of cement, used as binder, in the production of mortar, sandcrete blocks, lancrete bricks and concrete has led to a search for alternative. The overall relevance of concrete in virtually all civil engineering practice and building construction works cannot be overemphasized. The growing concern of resource depletion and global pollution has challenged many researchers and engineers to seek and develop new materials relying on renewable resources. These include the use of by-products and waste materials in building construction. Many of these by-products are used as aggregate for the production of lightweight concrete (Vishwas and Sanjay, 2013).

With the global economic recession coupled with the market inflationary trends, the constituent materials used for these structures had led to a very high cost of construction. On the other hand, building construction works and civil engineering practice in Nigeria depend, to a very large extent, on concrete as major construction material. The versatility, strength and durability of cement are of utmost priority over other construction materials. The basic materials for concrete are: cement, fine aggregate (sand), coarse aggregate (granite chippings or gravel) and water, the overall cost of concrete production depends largely on the availability of these constituents. Reduction in construction costs and the ability to produce light-weight concrete structures (LWC) are added advantages. The primary aim is to determining the suitability of partial replacement of cement with coconut shell ash (CSA) and palm kernel shell ash (PKSA) in concrete.

\section{Literature review}

Concrete is widely used as construction material for various types of structures due to its durability. For a long time it was considered to be very durable material requiring a little or no maintenance. Many environmental phenomena are known significantly the durability of reinforced concrete structures. We build concrete structures in highly polluted urban and industrial areas, aggressive marine environments and many other hostile conditions where 
other materials of construction are found to be nondurable. So the use of concrete is unavoidable. At the same time the scarcity of aggregates are also greatly increased nowadays. Utilization of industrial soil waste or secondary materials has been encouraged in construction field for the production of cement and concrete because it contributes to reducing the consumption of natural resources. They have been successfully used in the construction industry for partial or full replacement for fine and coarse aggregates.

Slim and Wakefield (1991) investigated the use of water works sludge in the manufacture of clay bricks. Osayemwen (1992) studied the use of periwinkle shells as alternative material to granite chips as coarse aggregate in concrete and concluded that the use of periwinkle shells for concrete would result in low cost housing delivery especially in the riverine areas where they are found as waste. Nimityongskul and Daladar (1995) investigated the use of coconut husk ash, corn cob ash and peanut shell ash as cement replacement in concrete production. Falade (1995) also carried out investigation on the use of periwinkle shells partially or wholly in concrete. The results of the investigation showed that the workability of the concrete batches, density, compressive and flexural strengths of specimens tested decreased with increase in the proportion of periwinkle shells to granite in the mixes. Ndoke (2006) investigated the suitability of palm kernel shells as partial replacement for coarse aggregates in asphaltic concrete. Olanipekun et al. (2006) compared concrete made with coconut shells and palm kernel shells as replacement for coarse aggregates and concluded that coconut shells performed better than palm kernel shells.

Osarenmwinda et al. (2009) investigated the potential of periwinkle shell as coarse aggregate for concrete. The results showed that concretes produced with ratio 1:1:2, 1:2:3 and 1:2:4 mixes indicated compressive strengths of $25.67 \mathrm{~N} / \mathrm{mm}^{2}, 19.5 \mathrm{~N} / \mathrm{mm}^{2}$ and $19.83 \mathrm{~N} / \mathrm{mm}^{2}$ at 28 days curing age respectively. These strength values met the ASTM-77 recommended minimum strength of $17 \mathrm{~N} / \mathrm{mm}^{2}$ for structural light weight concrete while the mixes with compressive strengths of $14 \mathrm{~N} / \mathrm{mm}^{2}$ and $16.5 \mathrm{~N} / \mathrm{mm}^{2}$ respectively did not meet the standard values. In a research carried out by Olutoge (2010), he investigated the suitability of sawdust and palm kernel shells as replacement for fine and coarse aggregates in the production of reinforced concrete slabs. He concluded that $25 \%$ sawdust and palm kernel substitution reduced the cost of concrete production by $7.45 \%$. He also indicated the possibility of partially replacing sand and granite with sawdust and palm kernel shell in the production of lightweight concrete slabs. Also, Falade et al (2010) investigate the behaviour of lightweight concrete containing periwinkle shells at elevated temperature; the parameters that were measured are compressive strength, density and bond characteristics of the concrete matrix. The results showed that the compressive strength of concrete decreased with increase in water/cement ratio and temperature but increased with increase in curing age and cement content while the density decreased with increase in temperature. They affirm that lightweight concrete containing periwinkle shells is only suitable for structures that will be subjected to temperature less than $300^{\circ} \mathrm{C}$

\section{Materials and methods}

The materials used for this study include:

- Ordinary Portland Cement (Dangote Cement)

- Coarse aggregate made of shippings from Johnson quarry in Akure;

- Fine aggregate (river sand) from Ala river in Akure;

- Palm kernel shell: Palm kernel shell (Abiola, 2006) is the hard endocarp of palm kernel fruit that surrounds the palm kernel seed of the oil palm tree (Elaeisguineensis).

- Coconut shell: The Coconut shell used for the experiment was obtained from Badagry town in Lagos. 
The palm kernel tree is native of West Africa as well as widely spread throughout the tropics. It grows to about $9 \mathrm{~m}$ in height and characterized with a crown of feathery leaves that are up to 5 $\mathrm{mm}$ long. Flowering is followed by the development of cluster of egg-shaped red, orange or yellowish fruits, each about $3 \mathrm{~cm}$ long. Palm kernel shells are obtained as crushed pieces after threshing or crushing to remove the palm seed after the production of palm kernel oil. It is estimated that the palm kernel shell constitutes about $34.5 \%$ of a single ripe, fresh fruit (Aragbaiye, 2007). Palm kernel shells are derivable in large quantities and their disposal has continued to constitute major environmental problems. Figure 1 shows the palm kernel shell.

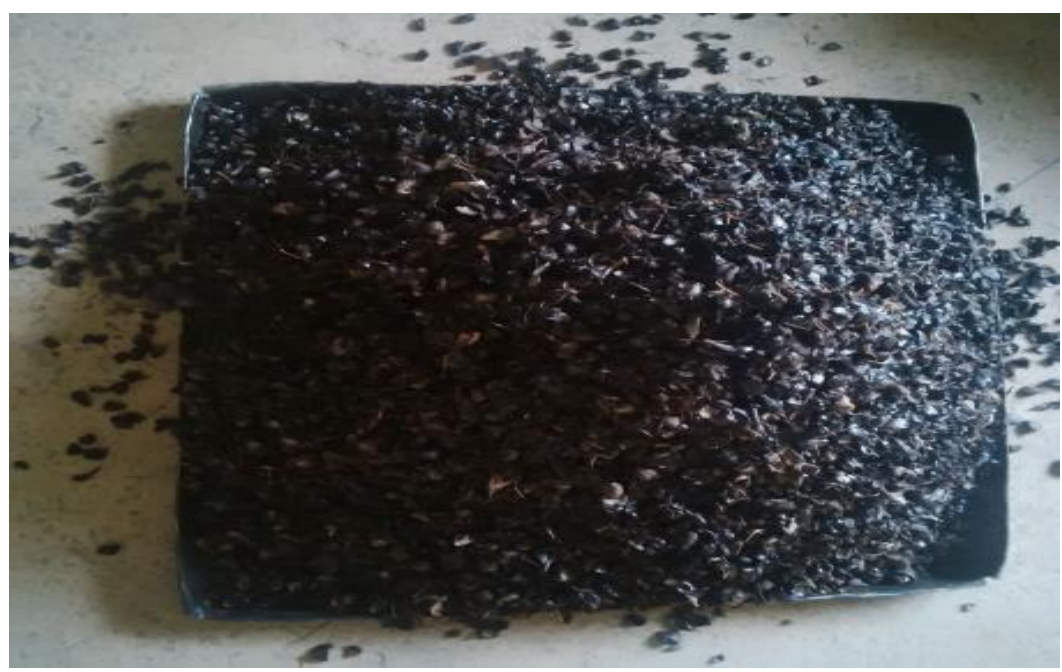

Fig 1. Palm kernel shell.

Coconuts (cocosnucifera) are referred to as "man's most useful trees", "king of the tropical flora" and "tree of life". Coconuts are the most important of cultivated palms and the most widely distributed of all palms. Coconut is a tall cylindrical-stalked palm tree, reaching $30 \mathrm{~m}$ in height and $60-70 \mathrm{~cm}$ in diameter. It is a tropical plant for low altitudes and generally suitable for cultivation in sandy seashore. The most important part of the tree is its fruit, which is eggshaped, about $30 \mathrm{~cm}$ long and $25 \mathrm{~cm}$ in diameter. The more external layer of the fruit is thin and smooth, its fibrous mesocarp is $3-5 \mathrm{~cm}$ thick and the endocarp is very hard. The fruit has a large central cavity, which contains a sweet liquid (coconut water). The fruit is ovid in shape and in the husk is about the six of a football. The fruit consists of 4 parts: about $35 \%$ husk, $12 \%$ shell, $28 \%$ meat and $25 \%$ water. Figure 2 shows different sizes of coconut shell.

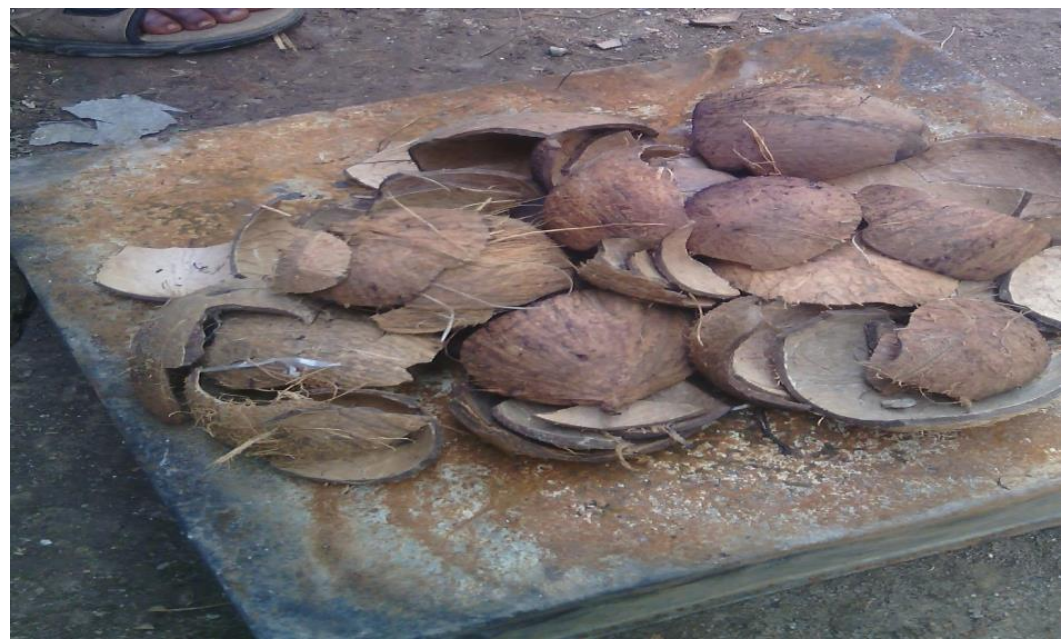

Fig 2. Different sizes of coconut shell.

The palm kernel shell (PKS) and coconut shell (CK) was sun dried for 48 hours to remove moisture from it. It was then subjected to internal combustion using a furnace, burnt for $24-48$ hours and allowed to cool for about 12 hours. The burnt ash was collected and sieved through a 
BS sieve (75 microns). The resulting palm kernel shell ash (PKSA) and coconut shell ash (CSA) which has the required fineness was collected for use, Figure 3 is the particle size distribution performed on the fine aggregate. Using a mix design ratio of 1:2:4 and water binder ratio of 0.63 , a total of one hundred and forty four concrete cubes of size 150x150x150 mm were casted using varying OPC : PKSA and OPC : CSA ratios of 100:0 , 90:10, 80:20, 70:30, 60:40 and 50:50 respectively i.e. 12 cubes for each percentage of replacement. The cubes were cured and crushed after 7, 14, 21 and 28 days respectively to determine the compressive strength. The various tests carried on the materials used for the experiment are: sieve analysis for fine aggregate, slump test for concrete, compaction factor, compressive strength test, aggregate impact value test and aggregate crushing value test.

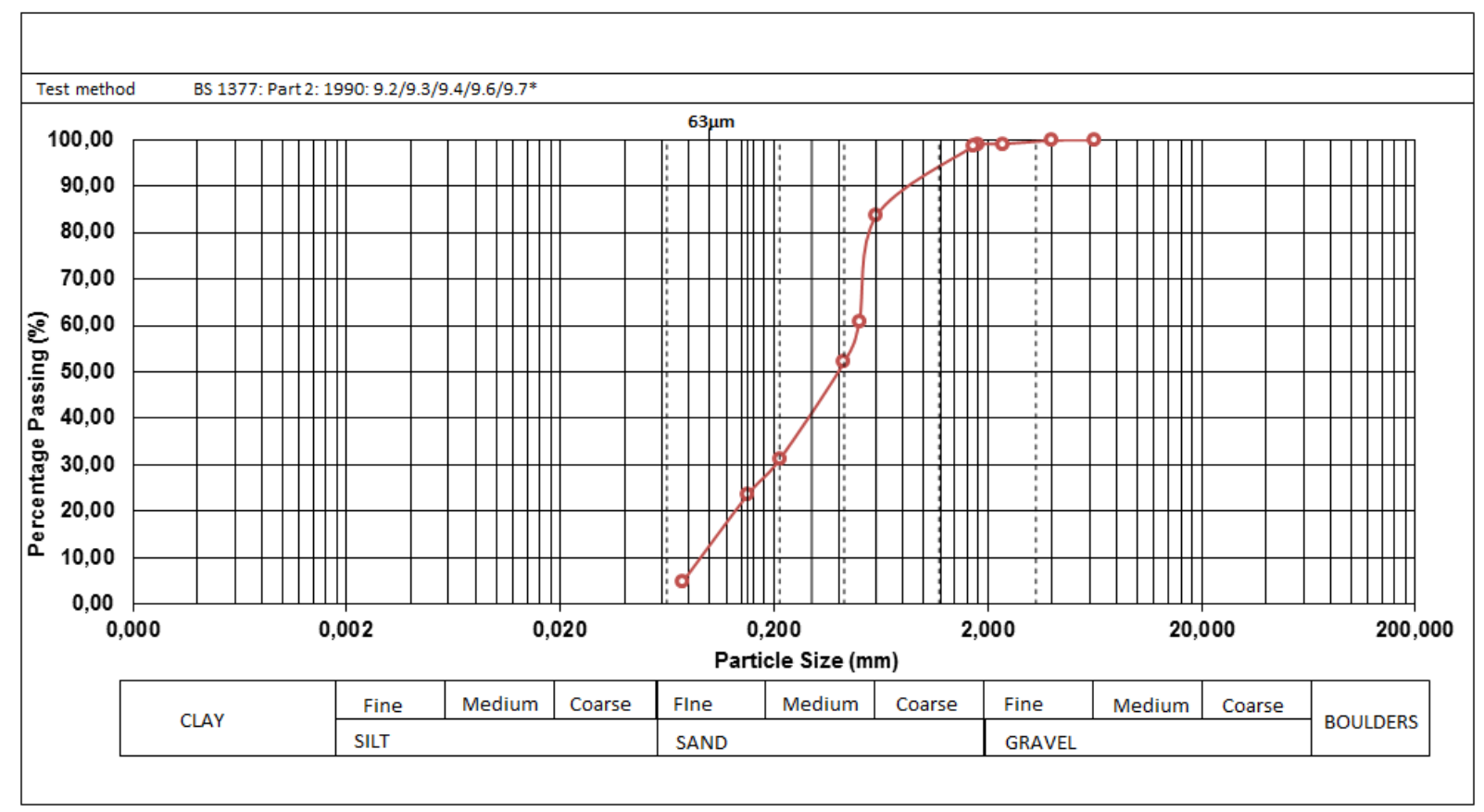

Fig 3. Particle size distribution analysis of fine aggregate.

From the curve obtained:

$D_{60}=0.48 ; D_{30}=0.2 ; D_{10}=0.08$

$C_{u}=\frac{D_{60}}{D_{10}}=\frac{0.48}{0.08}=6.0$

$C_{c}=\frac{\left(D_{30}\right)^{2}}{D_{10} D_{60}}=\frac{0.2^{2}}{0.08 \times 0.48}=1.04$

Where:

- $D_{60}$ is the particle diameter, at which 60 percent by weight of the soil is finer,

- $D_{30}$ is particle diameter, at which 30 percent by weight of the soil is finer,

- $\quad D_{10}$ is particle diameter, at which 10 percent by weight of the soil is finer,

- $\quad C_{u}$ is the coefficient of uniformity and $C_{c}$ is the coefficient of curvature.

Note: A well graded soil has a $C_{u}$ value of 5 or more; thus, the fine soil is well graded since the $C_{u}$ is 6 , i.e. more than 5 . 
Calculation of Aggregate Crushing Value (Granite)

Weight retained on $10 \mathrm{~mm}$ BS Sieve (M1) $=480.0 \mathrm{~g}$

Weight retained on $2.36 \mathrm{~mm}$ BS Sieve (M2) = $299.0 \mathrm{~g}$

Weight passing through $2.36 \mathrm{~mm}$ BS Sieve (M3) $=152.0 \mathrm{~g}$

$\mathrm{ACV}=\frac{\mathrm{M}_{3}}{\mathrm{M}_{1}} \mathrm{X} 100 \%=\frac{152.0}{480.0} \mathrm{X} 100 \%=31.59 \%$

Similarly, the value of Aggregate Impact Value (Granite) is calculated in the same manner.

Aggregate Impact Value $=22.61$.

Remark: The value obtained is 22.61 which are within the acceptable limit of +3 to -3 .

\section{Results}

Table 1 and Table 2 are the summary of results of the test carried out on the concrete mixes; while Table 3 is suggested values of workability. Figure 4 and Figure 5 show the compressive strength variations of partial replacement of cement with PKSA and CSA respectively.

Table 1. Results of the test carried out on the concrete mix for PKSA.

\begin{tabular}{|c|c|c|c|c|c|c|c|}
\hline $\begin{array}{c}\text { Replacement } \\
(\%)\end{array}$ & $\begin{array}{c}\text { Slump } \\
(\mathrm{mm})\end{array}$ & $\begin{array}{c}\text { Fully } \\
\text { compacted } \\
\text { concrete (fc) }\end{array}$ & $\begin{array}{c}\text { Partially } \\
\text { compacted } \\
\text { concrete }\end{array}$ & $\begin{array}{c}\text { Compacting } \\
\text { factor (pc/fc) }\end{array}$ & $\begin{array}{c}\text { Air } \\
\text { entrainment } \\
(\%)\end{array}$ & Pressure & $\begin{array}{c}\text { Water } \\
\text { cement ratio }\end{array}$ \\
\hline \hline 0 & 55 & 17.2 & 15.2 & 0.90 & 1.5 & 1.5 & 0.55 \\
\hline 10 & 35 & 17.2 & 15.6 & 0.90 & 0.5 & 1.5 & 0.61 \\
\hline 20 & 50 & 17.1 & 16.4 & 0.95 & 0.5 & 1.5 & 0.63 \\
\hline 30 & 38 & 17.1 & 16.0 & 0.93 & 1.2 & 1.5 & 0.55 \\
\hline 40 & 33 & 17.2 & 15.8 & 0.91 & 0.8 & 1.5 & 0.63 \\
\hline 50 & 35 & 17.1 & 16.8 & 0.98 & 0.6 & 1.5 & 0.55 \\
\hline
\end{tabular}

Table 2. Results of the test carried out on the concrete mix for CSA.

\begin{tabular}{|c|c|c|c|c|c|c|c|}
\hline $\begin{array}{c}\text { Replacement } \\
(\%)\end{array}$ & $\begin{array}{c}\text { Slump } \\
(\mathrm{mm})\end{array}$ & $\begin{array}{c}\text { Fully } \\
\text { compacted } \\
\text { concrete (fc) }\end{array}$ & $\begin{array}{c}\text { Partially } \\
\text { compacted } \\
\text { concrete }\end{array}$ & $\begin{array}{c}\text { Compacting } \\
\text { factor (pc/fc) }\end{array}$ & $\begin{array}{c}\text { Air } \\
\text { entrainment } \\
(\%)\end{array}$ & Pressure & $\begin{array}{c}\text { Water } \\
\text { cement ratio }\end{array}$ \\
\hline \hline 0 & 60 & 17.6 & 16.5 & 0.94 & 1.2 & 1.5 & 0.5 \\
\hline 10 & 65 & 17.58 & 16.4 & 0.93 & 1.0 & 1.5 & 0.55 \\
\hline 20 & 65 & 17.8 & 16.65 & 0.94 & 0.8 & 1.5 & 0.6 \\
\hline 30 & 55 & 17.75 & 16.8 & 0.93 & 0.6 & 1.5 & 0.61 \\
\hline 40 & 40 & 17.63 & 16.61 & 0.94 & 0.61 & 1.5 & 0.64 \\
\hline 50 & 55 & 17.5 & 16.1 & 0.92 & 1.0 & 1.5 & 0.64 \\
\hline
\end{tabular}

Table 3. Suggested values of workability.

\begin{tabular}{|c|c|c|c|}
\hline Application & Slump (mm) & $\begin{array}{c}\text { Compaction } \\
\text { Factor }\end{array}$ & $\begin{array}{c}\text { Time in } \\
\text { Vee-Bee (s) }\end{array}$ \\
\hline \hline $\begin{array}{c}\text { 1. Concreting of shallow } \\
\text { sections with vibrations }\end{array}$ & - & $0.75-0.80$ & $10-20$ \\
\hline $\begin{array}{c}\text { 2. Concreting in light reinforced } \\
\text { sections in vibrators }\end{array}$ & - & $0.80-0.85$ & $5-10$ \\
\hline $\begin{array}{c}\text { 3. Concreting of lightly } \\
\text { reinforced sections with } \\
\text { vibrations }\end{array}$ & $25-75$ & $0.85-0.92$ & $2-5$ \\
\hline $\begin{array}{c}\text { 4. Concreting of heavily } \\
\text { reinforced sections without } \\
\text { vibration }\end{array}$ & $75-125$ & More than 0.92 & - \\
\hline
\end{tabular}

As can be seen from Table 1 and Table 2, slump test results for concrete using PKSA and CSA with water cement ratio of 0.63 gives a slump value between 33 to $55 \mathrm{~mm}$ and 40 to $65 \mathrm{~mm}$ 
respectively; when compared with the suggested value for workability in Table 3 , the average value of the slump is classified as a true slump.

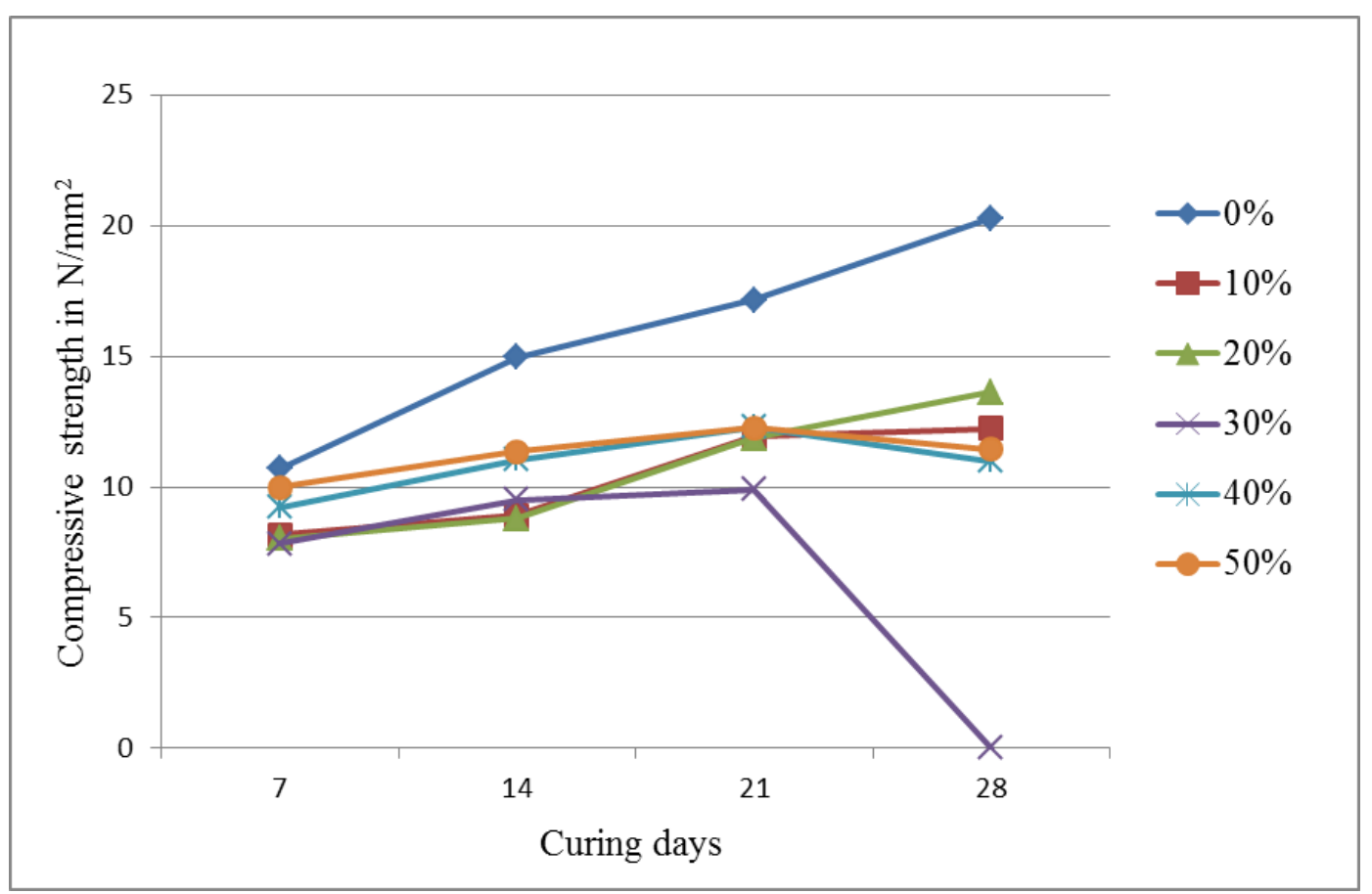

Fig 4. Strength Variations with Partial Replacement of Cement with PKSA.

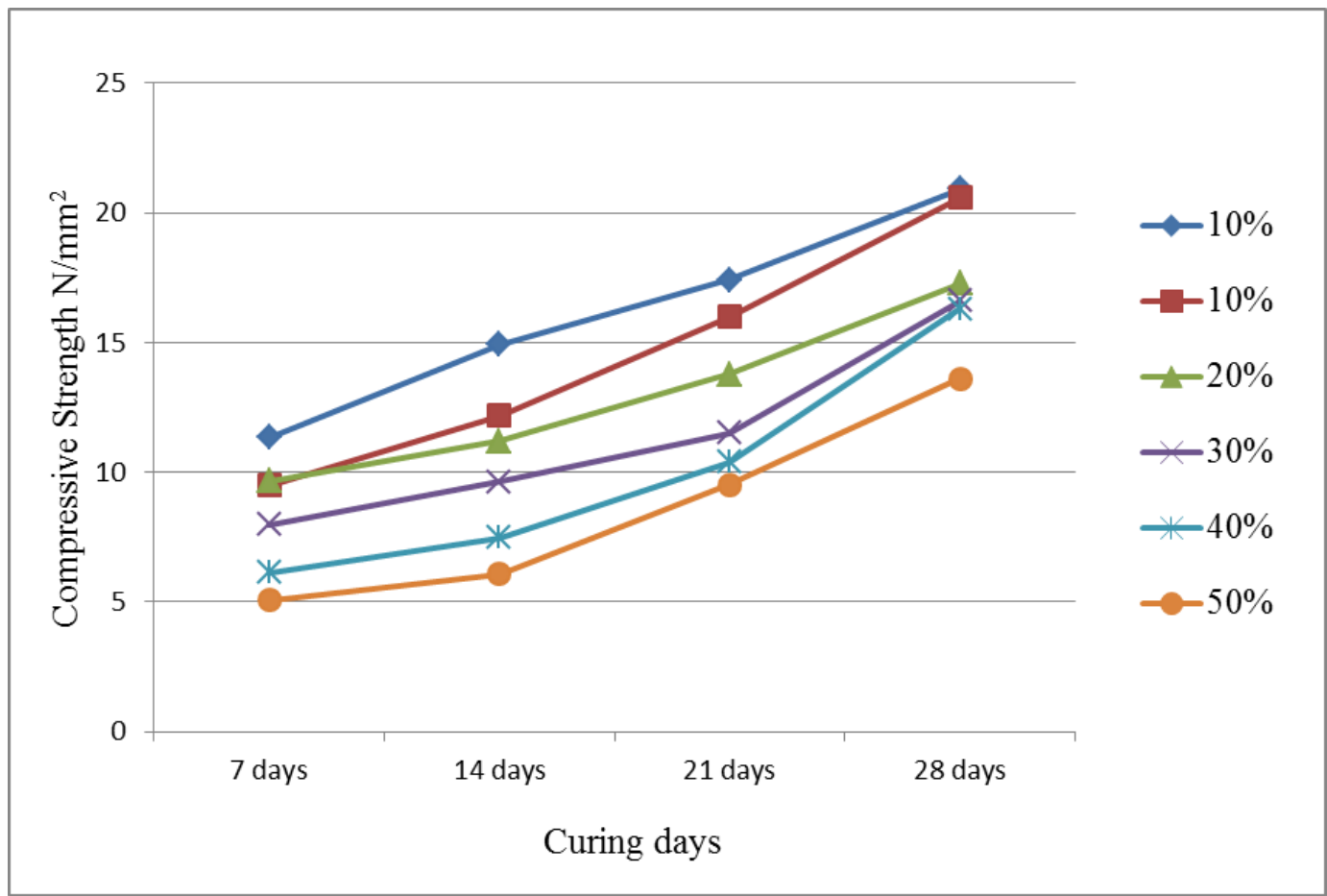

Fig 5. Compressive Strength Variations with Partial Replacement of Cement with CSA.

The average optimum compressive strength obtained at 28 days is $15.4 \mathrm{~N} / \mathrm{mm}^{2}$ at $20 \%$ replacement of cement with PKSA (Figure 4). Thus, the value obtained is suitable for light weight aggregate which falls within $15-25 \mathrm{~N} / \mathrm{mm}^{2}$ as specify in Rigid Pavement Design Manual (2009). However, the optimum value of compressive strength obtained at 28 days is $20.58 \mathrm{~N} / \mathrm{mm}^{2}$ at $10 \%$ replacement of cement with CSA which can be used for heavy weight concrete while 17.26 $\mathrm{N} / \mathrm{mm}^{2}$ obtained at $20 \%$ replacement is useful for light weight aggregate (Figure 5). 


\section{Conclusions}

Concrete is used for many structures basically for its compressive strength to support any type of load. This work has shown that partial replacement of cement with $20 \%$ palm kernel shell ash (PKSA) and coconut shell ash (CSA) in concrete gives an average optimum compressive strength of $15.4 \mathrm{~N} / \mathrm{mm}^{2}$ and $17.26 \mathrm{~N} / \mathrm{mm}^{2}$ respectively at 28 days. The value obtained is suitable for light weight aggregate. However, the optimum value of compressive strength obtained at 28 days is $20.58 \mathrm{~N} / \mathrm{mm}^{2}$ at $10 \%$ replacement of cement with CSA which can be used for heavy weight concrete. Thus, partially replaced cement with PKSA and CSA, using water cement ratio of 0.63 is suitable for the construction of light load structures such as floors lintels and low cost housing project;

The use of PKSA and CSA as a partial replacement of cement produced a cheaper structural lightweight concrete using the optimum compressive strength value specify in the research; the research shows that the use of PKSA and CSA as a partial replacement for cement in concrete, at lower volume of replacement, will enhance the reduction of cement usage in concretes, thereby reducing the production cost and the environmental pollution caused by the dumping of the agricultural waste.

\section{References}

Abiola OM. (2006). Characteristics of palm kernel shells powder as additive in sandcrete. Transaction of the Nigeria Society of Engineers, 2(1), 21-32.

Aragbaiye BA. (2007). Palm kernel shell as composite material in concrete. Unpublished B. Eng project report. Dept of Civil Engineering, University of Ilorin, Ilorin, 25-31.

Falade F (1995). An investigation of periwinkle shells as coarse aggregate in concrete. Building and Environment, 30(4), 573-577.

Falade F, Ikponmwosa EE and Ojediran NI. (2010). Behaviour of lightweight concrete containing periwinkle shell at elevated temperature. Journal of Engineering Science and Technology, 5(4), 379390.

Ndoke PN (2006). Performance of palm kernel shells as a partial replacement for coarse aggregate in asphalt concrete. Leonardo Electronic Journal of Practices and Technologies, 5(9), 145-152.

Nimityongskul P and Daladar TU. (1995). Use of coconut husk ash, corn cob ash and peanut shell ash as cement replacement. Journal of ferrocement, 25(1), 35-44.

Olanipekun E, Olusola K and Ata O. (2006). A comparative study of concrete properties using coconut shell and palm kernel shell as coarse aggregates. Building and Environment, 41(3), 297-301.

Olutoge F. (2010). Investigations on sawdust and palm kernel shells as aggregate replacement. ARPN Journal of Engineering and Applied Sciences, 5(4), 7-13.

Osayemwen EO. (1992). An investigation of the characteristics of lightweight concrete made of periwinkle shells, palm kernel shells, sand and sawdust as aggregates. Unpublished M.Sc. Dissertation. Department of Civil Engineering, University of Lagos. Nigeria.

Osarenmwinda J and Awaro A. (2009). The potential use of periwinkle shell as coarse aggregate for concrete. Advanced Materials Research, 62, 39-43.

Rigid Pavement Design Manual (2009). Published by Florida Department of Transportation. Pavement Management Office, 2(0).

Slim JA and Wakefield RW. (1991). The utilisation of sewage sludge in the manufacture of clay bricks. Water S. A., 17(3), 197-202.

Vishwas PK and Sanjay KBG (2013). Comparative study on coconut shell aggregate with conventional concrete. International Journal of Engineering and Innovative Technology, 2(12), 67-70. 